J. Perinat. Med.

2 (1974) 45

\section{First results and experiences with our prematurity and dysmaturity prevention program (PDP-Program)}

\author{
Jörg Michael Giffei, Erich Saling \\ Unit of Perinatal Medicine - The Free University of Berlin, \\ Department of Obstetrics and Gynecology, Berlin-Neukölln
}

Received October 26, 1973. Accepted December 20, 1973.
The mortality and morbidity of newborns with low birth-weight are considerably higher than in newborns with normal body-weight. The incidence of perinatal death and injury is highest in the low birth-weight group. In countries with low prematurity rates perinatal mortality is in most cases correspondingly low, e. g. Sweden and the Netherlands.

Hence the most pressing task of obstetrical and perinatal medicine is to lower the number of newborns with low birth-weight to the minimum.

PAPIERNIK [10] and our staff [12] have developed independently programs which can be used for evaluating in advance the risk of low birth-weight, so that appropriate measures can be taken in time.

\section{Development of our program}

The program was started in 1971 . We selected pregnant women at risk using a list of 36 risk factors. These factors were chosen on the basis of published data and our own clinical experience $[2,3,5,6,7,13,15,16]$.

They were separated into factor groups: nontreatable factors or factors of persisting risk after treatment (e. g. previous abortions or uterine bleeding early in gestation) and treatable or removable factors (e. g. smoking or development of gestosis).

We also determined whether the presence of the individual factor increases the risk of prematurity, dysmaturity or both.

Since there were no exact data available on the relative validity of each factor they were first

\section{Curriculum vitae}

Jörg Michael Giffei was born in 1942 in Königshofen (Bavaria) and attended school in Oldenburg (Oldbg.) and Hamburg. From 1962 be studied at the universities of Heidelberg, Hamburg, Marburg/Labn and at the Free University' of Berlin where be passed bis state-board-examinations in medicine in 1970. Since 1971 be bas been working as a member of the Unit for Perinatal Medicine at the Free University of Berlin. His main fields of interest: diabetes and pregnancy, problems of low birth-2weight infants.

registered in a PDP-list I [12], each factor having equal validity. This was known to be unsatisfactory but unavoidable if a start was to be made.

The list was filled in during the first examination of the pregnant woman at the clinic and supplemented as required during later visits.

If more than 2 risk factors indicated possible premature labor or 2 or more factors possible dysmaturity, the patient was given special prenatal care, described in more detail below.

A year later we evaluated our material. One of the first consequences was to change PDP-list I.

Instead of using factors of equal validity, each factor was assigned a certain number of points. This was an attempt to evaluate individual factor more precisely. PDP-list II resulted from this procedure (Fig. 1). 


\section{PDP-List II}

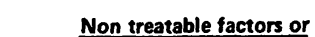

factors of persisting risk after treatmen

$$
\text { P. D. }
$$

1. General factors or factors darived from histon

Age $<20$ years and $\geqslant$ years $30 \ldots \ldots \ldots \ldots, \quad 1 \quad 1$

Previous 1.2 infants $\leqslant 2500 \mathrm{~g} \ldots \ldots \ldots \ldots \ldots \ldots . \ldots 2$

$\geqslant 3$ infants $\leqslant 2500 \mathrm{~g} \ldots \ldots \ldots \ldots \ldots . .4 \quad 4$

or abortions $1 \geqslant 2$, spontaneous! ............. $2 \quad 2$

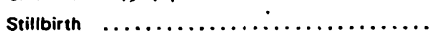

Neonatal death

Hight<160

Skeletal and pelvic anomalies

Too frequent pregnancies (less frequent
than 1 year)

Low body weight before pregnancy $(<55 \mathrm{~kg}$ ) ... $\quad 1 \quad 1$

2. Risk factors of present pregnancy

Treatable or removable factors

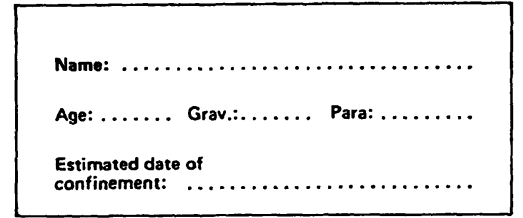

Poor or inadequate diet (e.g. $<50 \mathrm{~g}$ protein/day) Smoking $1-5$ cigarettes/day $6-20$ cigarettes/day $\frac{6 \cdot 20 \text { cigarettes/day }}{>20 \text { cigarettes/day }}$

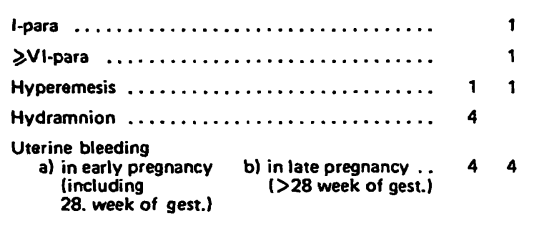

\section{Gestosis Age 20-29 ys.}
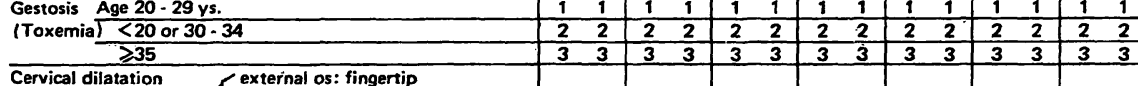

Cervical dilatation
or effacement

(when cervix sutured subtract 1 pt.)

in early pregnancy
including or cervical insufficiency or cervicat insufficiency
in previous pregnancies

Premature contractions \begin{tabular}{|l|l|l|l|l}
\hline Malposition of fetus (breech, etc.) & 4 \\
\hline Premature rupture of membrañes $>3$ weeks before term & 4 \\
\hline
\end{tabular} Premalle nadequate gain of weight or abdominal circumference

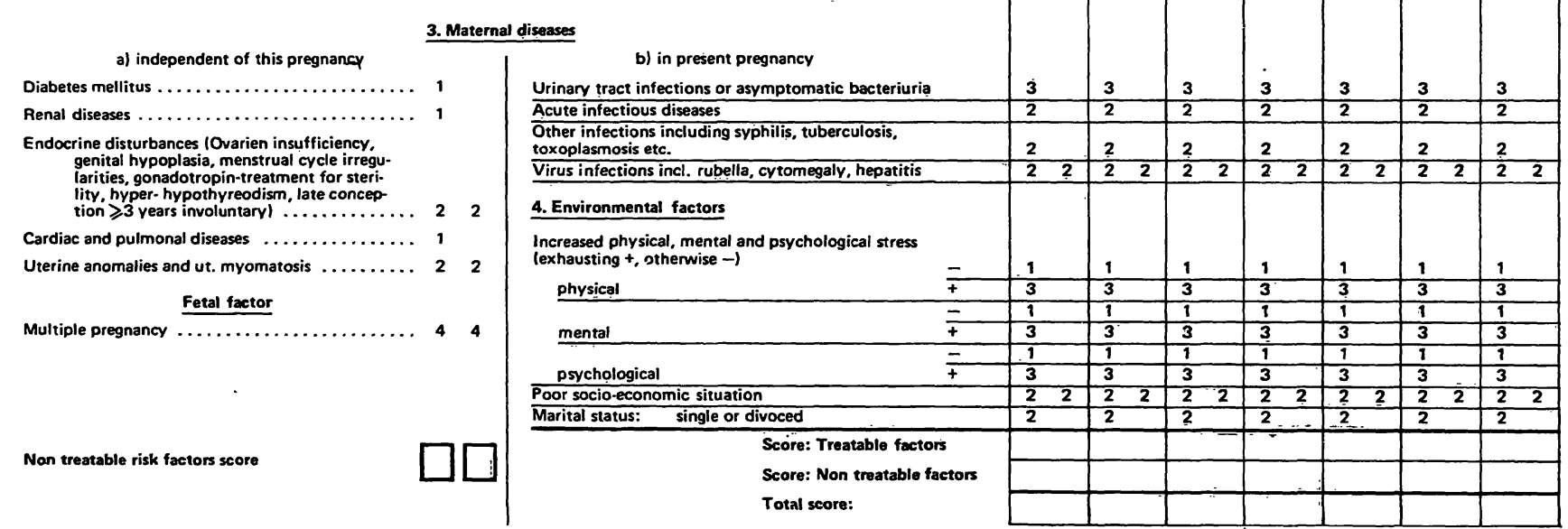

Fig. 1. PDP-list II for detection of potential risk of prematurity (P.) and dysmaturity (D.); I-para = patient exspecting first child.

We realize that this system may require further changes, as the greater number of patients observed according to this program will allow a better evaluation of factor validity.

In addition, our list is mainly concerned with the situation in central Europe. Modifications will be required for countries with different types of population and socio-economic structures.

\subsection{Results related to the degree of risk}

The point system of PDP-list II was retrospectively applied to PDP-list I in order to ascertain the lowest number of points indicating real danger. The results obtained in cooperation with HäUSSLER [cited in 13] are shown in Figs. 2 and 3. The risk of prematurity rises sharply at 6 points. For that reason all patients with 6 or more points are given special PDP=care. Nearly $95 \%$ of all pregnant women with risk of prematurity are thus covered.

The picture is not so clear for dysmaturity. Patients with 6 or more points are also selected for PDP-care. Thus we cover about $75 \%$ of pregnancies with risk of dysmaturity.

If all pregnancies of both prematurity and dysmaturity risk are included, about $40 \%$ of all our pregnant women have to be monitored. 


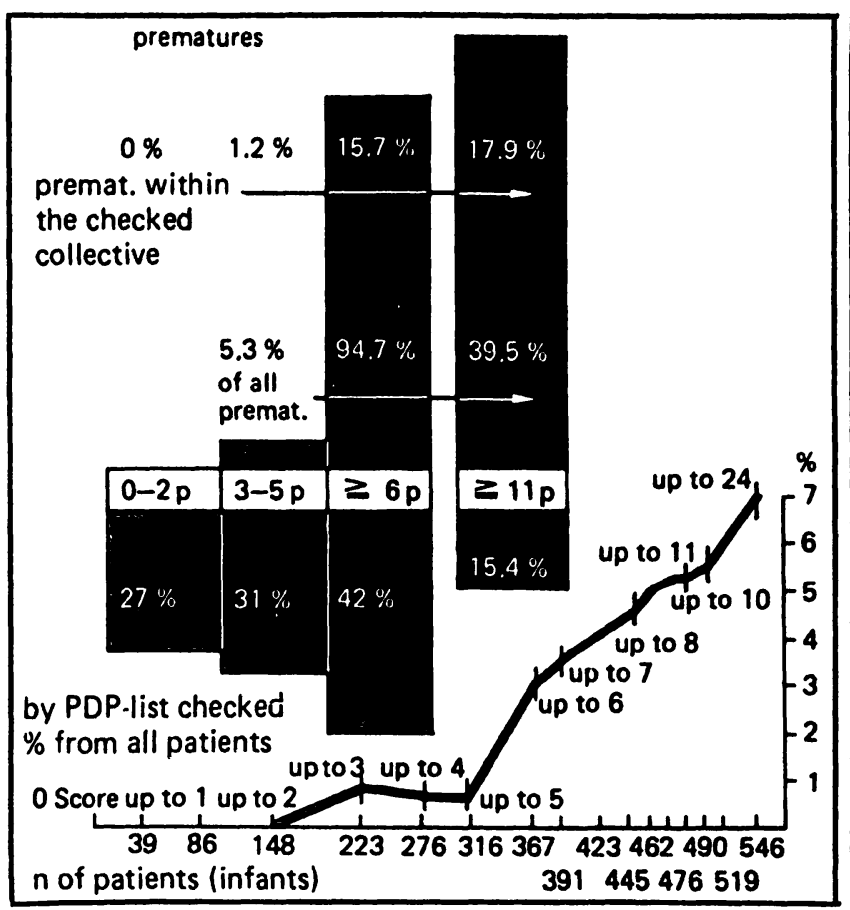

Fig. 2. 546 infants of 540 mothers checked by PDP-list analysed under the aspect of prematurity risk. The uppermost figures indicated by horizontal arrows show the frequency (\%) of prematurity in the particular point-group in relation to all 546 cases checked. In the second row from the top the frequency $(\%)$ of prematurity in the particular point-group in relation to all underweight infants is shown. The last row of figures within the columns shows the percentage of pregnant women requiring special prenatal care under this program in relation to the total number of prenatal-care-patients. The curve at bottom right shows the frequency $(\%)$ of prematurity in groups showing a certain number of points.

\subsection{Results related to a decrease in the rate of low birth-weight newborns}

Tab. I summarizes the results obtained in the first two years of this program. At the start the additional expenditure (mainly in form of staff

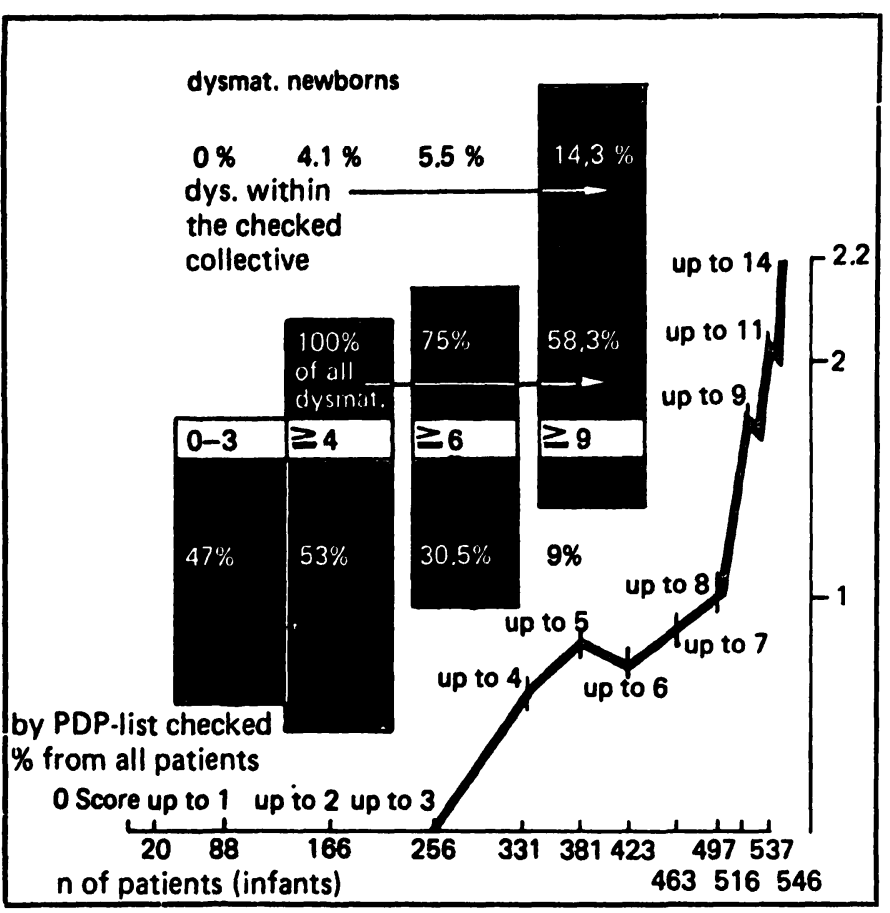

Fig. 3. 546 infants of 540 mothers checked by PDP-list analysed under the aspect of dysmaturity risk. See Fig. 2.

wages) required by the program was considerable, enabling us to check only $30 \%$ of all patients according to the PDP-list. The second year 50\% were checked.

It should be noted that we shall probably never be able to include all patients in the PDP-program, since about $30 \%$ are foreigners. A case history has to be taken, and this is rarely possible with the predominantly Turkish patients.

In reviewing our results, a comparison of Groups II and III is of particular interest. The frequency of newborns with a birth-weight of $2500 \mathrm{~g}$ or less is $1.9 \%$ lower in the latter group. That would indicate a $20 \%$ reduction of low birth-weight infants. This result was an encouraging first

Tab. I

\begin{tabular}{|c|c|c|c|}
\hline & \multirow{2}{*}{$\begin{array}{l}\text { Number of } \\
\text { born children }\end{array}$} & \multicolumn{2}{|c|}{ Birthweight $\leqq 2500 \mathrm{~g}$} \\
\hline & & Number & $\%$ \\
\hline \multicolumn{4}{|l|}{ August 1971-July 1972} \\
\hline I. Total amount & 1921 & 181 & 9.4 \\
\hline II. Not checked by PDP-list & 1353 & 135 & 10.0 \\
\hline III. By PDP-list checked and particularly managed if suspicious & 568 & 46 & 8.1 \\
\hline \multicolumn{4}{|l|}{ August 1972-July 1973} \\
\hline I. Total amount & 1697 & 129 & 7.6 \\
\hline II. Not checked by PDP-list & 850 & 80 & 9.4 \\
\hline III. By PDP-list checked and particularly managed if suspicious & 847 & 49 & 5.8 \\
\hline
\end{tabular}


Tab. II

\begin{tabular}{|c|c|c|c|}
\hline \multirow[t]{2}{*}{ By PDP-list checked collective } & \multirow{2}{*}{$\begin{array}{l}\text { Number of } \\
\text { born children }\end{array}$} & \multicolumn{2}{|c|}{ Birthweight $\leqq 2500 \mathrm{~g}$} \\
\hline & & Number & $\%$ \\
\hline \multicolumn{4}{|l|}{ August 1971-July 1972} \\
\hline Total amount & 568 & 46 & 8,1 \\
\hline A. Suspicious and managed & 232 & 25 & 10,8 \\
\hline B. Not suspicious (PDP-list I) and not particularly managed & 314 & 18 & 5,7 \\
\hline C. Suspicious but patients neglected further consequences & 22 & 3 & (13.6) \\
\hline \multicolumn{4}{|l|}{ August 1972-July 1973} \\
\hline Total amount & 847 & 49 & 5.8 \\
\hline A. Suspicious and managed & 302 & 28 & 9.3 \\
\hline B. Not suspicious (PDP-list II) and not particularly managed & 490 & 8 & 1.6 \\
\hline C. Suspicious but patients neglected further consequences & 55 & 13 & 23.6 \\
\hline
\end{tabular}

success with the yet relatively inexact selection list I.

The second year (Tab. I below) using PDP-list II, the incidence of newborns with low birthweight was decreased by $3.6 \%$ in Group III as compared with Group II ( $p<0.01)$, a reduction of more than $35 \%$ in the number of infants with a birth-weight of $2500 \mathrm{~g}$ or less.

Tab. II shows the further differentiation of Group III from Tab. I, providing the following interesting results: Section B according to PDP-list I (risk unsuspected) shows a still relatively high incidence of $5.7 \%$ of low birth-weight infants. The second year this figure was decreased to $1.6 \%$ using List II. This demonstrates the value of the improved point system. The decrease from $5.7 \%$ to $1.6 \%$ is statistically significant $(p<0.005)$.

\section{Practical procedures}

The outpatient clinic for this special purpose is organized differently than that for other patients. Whenever possible the same physician attends to the same patient thus ensuring continuity, better supervision and treatment of individuals.

More time is required for such consultation, since the patient is questioned more intensively and problems are explained to her more exactly. Thus she can, for instance, determine increased uterine activity herself and record the frequency and duration of contractions.

\subsection{Special examinations and therapy}

In addition, special examinations are performed routinely at certain intervals.
Thus during the initial consultation we perform a vaginal examination and we repeat this every 2 to 4 weeks, if not more frequently as indicated (e. g. by increased uterine activity). A point system is of value for recording cervical finding (Fig. 4). The early diagnosis of cervical incompetency is possible and operative therapy (cervical suture) can be applied.

Uterine contractions must be observed in this manner so that when the cervix becomes shorter and/or the cervical canal opens, tocolytic therapy with beta-mimetic drugs can be performed.

\subsubsection{Tocolytic therapy}

We are successfully using outpatient tocolytic therapy at very early stages of increased uterine activity, as we recommended in 1971 [12].

As suggested by Schwalm, cited by Mosler [9], we consider more than 10 contractions, or more than 5 per day lasting longer than $\mathbf{4 0}$ seconds as pathological (increased) uterine activity and therefore as an indication for oral therapy with beta-mimetic drugs. Unfortunately there are still no additional objective indications for likewisely early therapy since there are no data on the borderline between the physiological and pathological rate and duration of contractions, particularly in the everyday environment of the patient.

We are using Th 1165a (Partusisten®; BoEHRINGER, Ingelheim) combined if needed with Verapamil (Isoptin®; KNoLL AG). The latter inhibits the side-effects of Th $1165 \mathrm{a}$ on the 
Vag. examination for detection of cervical insufficiency

Name: Age:

Para:

Estimated date of confinement:

\begin{tabular}{|c|c|c|c|c|c|c|c|c|c|c|c|c|c|c|c|c|}
\hline \multicolumn{2}{|c|}{$\begin{array}{l}\text { Date } \\
\text { Time }\end{array}$} & 1 & 2 & 3 & 4 & 5 & 6 & 7 & 8 & 9 & 10 & 11 & 12 & 13 & 14 & 15 \\
\hline $\begin{array}{l}\text { Effacement: } \\
\text { no: } \\
\text { slight: } \\
\text { moderate: } \\
\text { complete: }\end{array}$ & $\begin{array}{l}3 \mathrm{~cm} \\
2 \mathrm{~cm} \\
1 \mathrm{~cm} \\
0 \mathrm{~cm}\end{array}$ & $\begin{array}{l}0 \\
1 \\
2 \\
3\end{array}$ & $\begin{array}{l}0 \\
1 \\
2 \\
3\end{array}$ & $\begin{array}{l}0 \\
1 \\
2 \\
3\end{array}$ & $\begin{array}{l}0 \\
1 \\
2 \\
3\end{array}$ & $\begin{array}{l}0 \\
1 \\
2 \\
3\end{array}$ & $\begin{array}{l}0 \\
1 \\
2 \\
3\end{array}$ & $\begin{array}{l}0 \\
1 \\
2 \\
3\end{array}$ & $\begin{array}{l}0 \\
1 \\
2 \\
3\end{array}$ & $\begin{array}{l}0 \\
1 \\
2 \\
3\end{array}$ & $\begin{array}{l}0 \\
1 \\
2 \\
3\end{array}$ & $\begin{array}{l}0 \\
1 \\
2 \\
3\end{array}$ & $\begin{array}{l}0 \\
1 \\
2 \\
3\end{array}$ & $\begin{array}{l}0 \\
1 \\
2 \\
3\end{array}$ & $\begin{array}{l}0 \\
1 \\
2 \\
3\end{array}$ & $\begin{array}{l}0 \\
1 \\
2 \\
3\end{array}$ \\
\hline Ext. os: & $\begin{array}{l}\text { closed } \\
\text { fingertip } \\
\text { finger } \\
\geqq 2 \mathrm{~cm}\end{array}$ & $\begin{array}{l}0 \\
1 \\
2 \\
3\end{array}$ & $\begin{array}{l}0 \\
1 \\
2 \\
3\end{array}$ & $\begin{array}{l}0 \\
1 \\
2 \\
3\end{array}$ & $\begin{array}{l}0 \\
1 \\
2 \\
3\end{array}$ & $\begin{array}{l}0 \\
1 \\
2 \\
3\end{array}$ & $\begin{array}{l}0 \\
1 \\
2 \\
3\end{array}$ & $\begin{array}{l}0 \\
1 \\
2 \\
3\end{array}$ & $\begin{array}{l}0 \\
1 \\
2 \\
3\end{array}$ & $\begin{array}{l}0 \\
1 \\
2 \\
3\end{array}$ & $\begin{array}{l}0 \\
1 \\
2 \\
3\end{array}$ & $\begin{array}{l}0 \\
1 \\
2 \\
3\end{array}$ & $\begin{array}{l}0 \\
1 \\
2 \\
3\end{array}$ & $\begin{array}{l}0 \\
1 \\
2 \\
3\end{array}$ & $\begin{array}{l}0 \\
1 \\
2 \\
3\end{array}$ & $\begin{array}{l}0 \\
1 \\
2 \\
3\end{array}$ \\
\hline Int. os.: & $\begin{array}{l}\text { closed } \\
\text { fingertip } \\
\text { finger } \\
\geqq 2 \mathrm{~cm}\end{array}$ & $\begin{array}{l}0 \\
1 \\
2 \\
3\end{array}$ & $\begin{array}{l}0 \\
1 \\
2 \\
3\end{array}$ & $\begin{array}{l}0 \\
1 \\
2 \\
3\end{array}$ & $\begin{array}{l}0 \\
1 \\
2 \\
3\end{array}$ & $\begin{array}{l}0 \\
1 \\
2 \\
3\end{array}$ & $\begin{array}{l}0 \\
1 \\
2 \\
3\end{array}$ & $\begin{array}{l}0 \\
1 \\
2 \\
3\end{array}$ & $\begin{array}{l}0 \\
1 \\
2 \\
3\end{array}$ & $\begin{array}{l}0 \\
1 \\
2 \\
3\end{array}$ & $\begin{array}{l}0 \\
1 \\
2 \\
3\end{array}$ & $\begin{array}{l}0 \\
1 \\
2 \\
3\end{array}$ & $\begin{array}{l}0 \\
1 \\
2 \\
3\end{array}$ & $\begin{array}{l}0 \\
1 \\
2 \\
3\end{array}$ & $\begin{array}{l}0 \\
1 \\
2 \\
3\end{array}$ & $\begin{array}{l}0 \\
1 \\
2 \\
3\end{array}$ \\
\hline Score: & & & & & & & & & & & & & & & & \\
\hline Examiner: & & & & & & & & & & & & & & & & \\
\hline
\end{tabular}

Fig. 4. Point system for evaluating the cervical finding in respect to the risk of prematurity.

maternal heart ("palpitation"). Our tablets contain $2.5 \mathrm{mg}$ Th $1165 \mathrm{a}$. The usual dose is $6 \times 1 / 2$ a tablet daily, taken at intervals of no more than 4 hours. If necessary the dose may be increased without risk to 6 tablets daily. (True premature labor of course must be treated by intravenous infusions of Th 1165a.) WEIDINGER et al. [17] give up to $6 \times 5 \mathrm{mg}$ daily, which may, however, lower the subjective wellbeeing of the patient considerably.

One Isoptin retard dragee contains $120 \mathrm{mg}$ Isoptin-hydrochloride. Depending on the dose of Th 1165 a up to 3 dragees a day are administered.

Numerous data are available on the side-effects of beta mimetic substances taken over prolonged periods $[11,17]$. Serious harm to mother or fetus has not been noted.

\subsubsection{Further important measures to prevent premature labor}

These include recommendation of work stoppage or, if the risk is high, of bed rest.

In addicion, the character of the risk factors has many possible consequences. Exact descriptions are not required here since it is well known that e. g. gestosis (toxemia) or an infection during pregnancy must be treated adequately.

\subsubsection{Management of the risk of dysmaturity}

In patients with dysmaturity risk, fetal growth should be monitored with ultrasound. Determination of the biparietal head diameter alone is not completely adequate. If, however, the transversal thorax diameter is taken as an additional measure of the fetus, a more precise determination of fetal size is obtained.

We use the nomogram published by HaNSMANN and Vorgt (Fig. 5, left top) which enables us to estimate body-weight more accurately. According to the author, the deviation from the actual weight is less than $10 \%$ in $80 \%$ of all cases.

Fetal measurements are taken, depending on the individual case, at 2 to 4 week intervals so that an increasing deviation from the norm can be seen in time.

The diagnosis of dysmaturity becomes more probable if other findings confirm a nutritive placental insufficiency. 


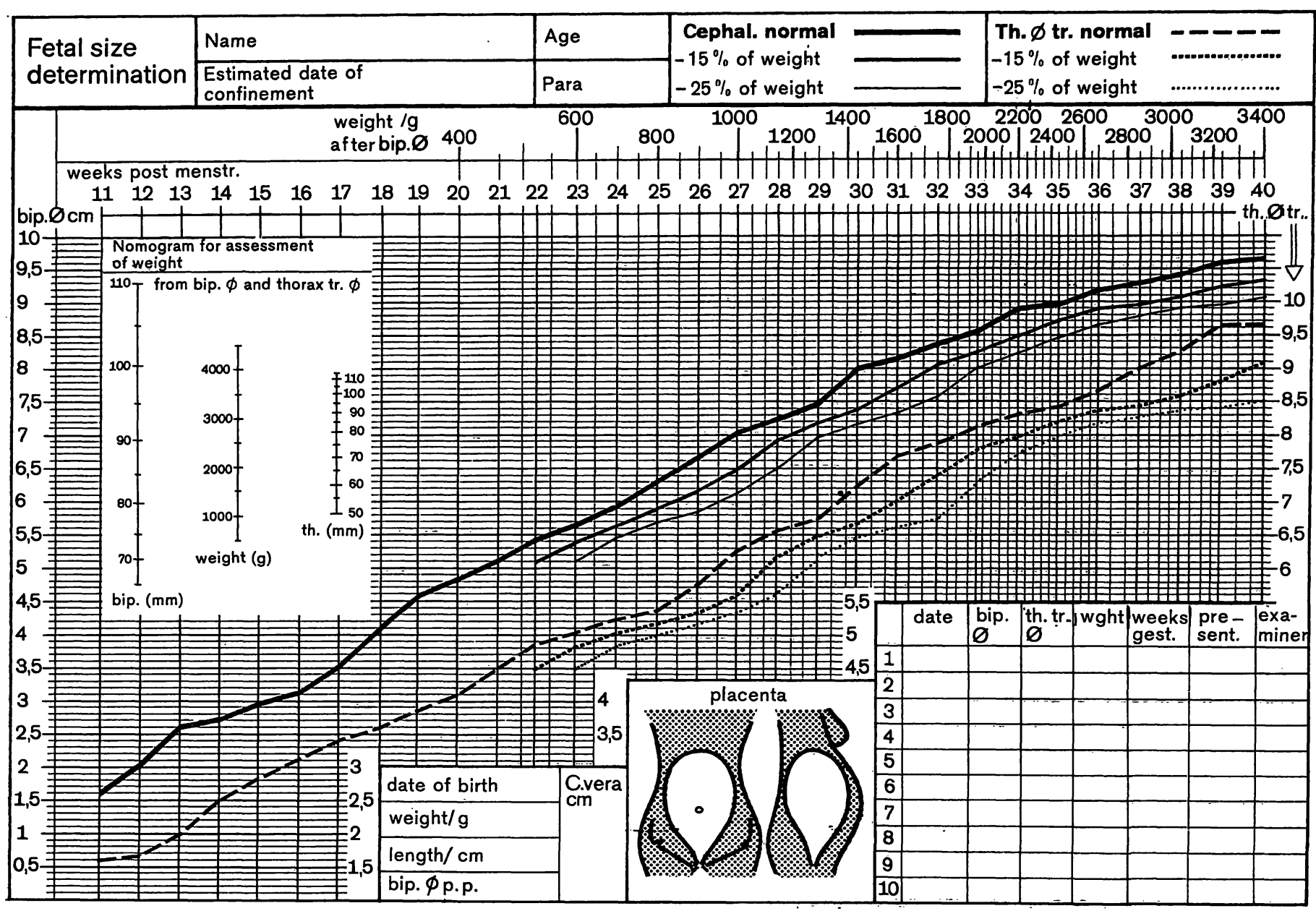

Fig. 5. Nomogram for ultrasonic determination of fetal size measuring biparietal head diameter and transversal thorax diameter.

We use HPL as the main indicator. Urinary estrogen determinations are used to a lesser extent.

In order to diagnose the additional respiratory insufficiency of the placenta frequently occurring in later stages of pregnancy, amniocentesis or amnioscopy together with cardiotocography are performed.

The most important therapeutic measure in intrauterine malnutrition is bed rest.

All other measures, e. g. heparin therapy $[1,8]$, tocolysis or other drug treatment to improve

\section{Summary}

The majority of perinatal deaths and injuries occur in cases of low birth-weight ( $2500 \mathrm{~g}$ and less). Hence obstetrical and perinatal medicine is urgently pressed to decrease the number of low birth-weight newborns.

We started our PDP-program in 1971. It is based on the PDP-list filled in during the first consultation with the uterine blood flow and supply of amino acids into amniotic cavity as we have proposed $[4,14]$ have not been tested sufficiently to recommend them for routine clinical use.

\section{Conclusion}

Realization of the PDP-program requires considerable staff and equipment expense. However, a clear decrease in the frequency of low birth-weight infants has already been achieved during the short time this program has been in effect.

pregnant woman and supplemented during further examinations.

The list contains 36 risk factors separated into two factor groups: non-treatable factors or factors of persisting risk after treatment and treatable or removable factors. 
All risk factors are differentiated according to their significance for pre- or dysmaturity.

The first year PDP-list I gave equal validity to all factors. The second year, factors were weighed according to a point system expressed in PDP-list II (Fig. 1).

From 6 points the prematurity risk and less distinctly also the dysmaturity risk increase unequivocally (Figs. 2 and 3).

About $40 \%$ of all patients showed this number of points and were supervised in a special prenatal-care clinic.

Tab. 1 summarizes results obtained in the first two years. The first year (Tab. I above) only $30 \%$ of all pregnancies could be checked using the PDP-list due to the expense of additional staff, the second year we covered $50 \%$ (Tab. I below).

In Group III there were $1.9 \%$ fewer low birth-weight infants than in Group II which was not thus examined. The second year this difference reached 3.6\%. This represents a total reduction in the number of infants with low birth-weight by more than $35 \%$ (significant for $\mathrm{p}<0.01$ ).

In Tab. II Group III of Tab. I is further differentiated.

The first year the incidence of $5.7 \%$ low birth-weight infants in Section B (not at risk according to PDP-list I) was still too high.

Using PDP-list II in the second year the percentage was decreased to $1.6 \%$. This decrease is significant for $\mathrm{p}<0.005$ and demonstrates the better selection due to the point system of PDP-list II.

The PDP outpatient-care differs from other prenatal-care as follows:
1. Whenever possible, the patient is always examined by the same doctor. This ensures better treatment and a continuity in medical findings.

2. More time per patient for questioning, information and examinations usually not performed to such an extent.

3. Vaginal examinations every 2 to $\mathbf{4}$ weeks, if not more frequently as indicated. Recording the cervical finding (Fig. 4).

4. Outpatient tocolysis with beta-mimetic drugs at very early stages of increased uterine activity; this means: more than 10 contractions/day or more than 5/day lasting longer than $40 \mathrm{sec}$. Dosage: Partusisten $®$ (Th 1165a), $6 \times 1.25 \mathrm{mg} /$ day up to $6 \times 2.5 \mathrm{mg} /$ day, combined if needed with Isoptin ${ }^{\circledR}$ retard (Verapamil), depending on the extent of side-effects up to $3 \times 120 \mathrm{mg} /$ day.

5. Control of fetal growth by ultrasound cephalo-thoracometry every 2 to 4 weeks (Fig. 5). If the curve so indicates, HPL determinations to diagnose nutritive placental insufficiency.

6. In late pregnancy amnioscopy and cardiotocography to determine respiratory placental insufficiency.

Realization of the PDP-program requires considerable staff and equipment. However, a clear decrease in the frequency of low birth-weight newborns has already been achieved during the short time the program has been in effect.

Keywords: Cephalo-thoraco-metry, dysmaturity, prematurity, prenatal-care, risk-list, tocolysis.

\section{Zusammenfassung}

Erste Erfahrungen und Ergebnisse mit unserem Prämaturitäts- und Dysmaturitäts-Präventions-Programm (PDP-Programm)

Der Hauptanteil der perinatal verstorbenen oder geschädigten Kinder entstammt dem Kollektiv der Neugeborenen mit niedrigem Geburtsgewicht ( $\leq 2500 \mathrm{~g})$. Es ist daher eine vordringliche Aufgabe der Geburts- und Perinatal-Medizin, die Zahl der untergewichtigen Kinder zu senken. 1971 begannen wir mit der Anwendung unseres PDP-Programmes. Das Kernstück ist die PDP-Liste, die bei der ersten Beratung mit der Schwangeren ausgefüllt und bei den weiteren Untersuchungen ergänzt wird. Die Liste stellt einen Katalog von 36 Risikofaktoren dar, die graphisch getrennt wurden in Faktoren mit nicht mehr abstellbarer Belastung, die sogenannten „feststehenden Faktoren" und in abstellbare oder behandelbare Faktoren, wobei auch hinsichtlich ihrer Bedeutung in Richtung Prä- oder Dysmaturitäts-Gefährdung differenziert wird. Im ersten Anwendungsjahr stellte die PDP-Liste I die Faktoren noch gleichwertig nebeneinander. Im zweiten Jahr wurde nach Auswertung der Ergebnisse der Versuch gemacht, durch ein Punktesystem die einzelnen Faktoren auch in ihrer unterschiedlichen Wertigkeit besser zu erfassen. Es entstand die PDP-Liste II (Fig. 1).
Ein eindeutiges Prämaturitätsrisiko besteht ab 6 Punkten aufwärts (Fig. 2), ein Dysmaturitätsrisiko nicht ganz so deutlich ebenfalls ab 6 Punkten (Fig. 3). Etwa 40\% aller Schwangeren erreichten bei uns diese Punktezahl und wurden in einer eigens für sie eingerichteten Sprechstunde betreut. Die in den ersten beiden Jahren erzielten Ergebnisse zeigt Tab. I. Im ersten Jahr (oberer Teil der Tab. I) konnten wir wegen des zusätzlichen Aufwandes nur knapp 30\% aller Schwangeren mit der PDP-Liste erfassen. In diesem Kollektiv III waren 1,9\% weniger untergewichtige Kinder zu verzeichnen als im nicht erfaßten Kollektiv II. Im zweiten Jahr (unterer Teil der Tab. I) betrug dieser Unterschied 3,6\%. Das bedeutet eine Gesamtreduzierung der untergewichtigen Kinder um mehr als $35 \%$ (statistisch signifikant mit $\mathrm{p}<0,01$ ).

In Tab. II ist das Kollektiv III der Tab. I weiter differenziert. Im ersten Jahr war die Untergewichtigen-Rate in Gruppe B (nach PDP-Liste I ,nicht gefährdet“) mit 5,7\% noch zu hoch. Durch den Einsatz der PDP-Liste II im zweiten Jahr konnte die Rate der untergewichtigen Kinder in Gruppe B auf 1,6\% gesenkt werden. Der Abfall ist mit $\mathrm{p}<0,005$ statistisch signifikant und beweist die bessere Selektion durch das Punktesystem der Liste II. 
Dic PDP-Sprechstunde unterscheidet sich von den anderen Klinik-Sprechstunden in folgenden Punkten:

1. Betreuung der Patientin von immer demselben Kollegen; dadurch wird eine bessere Übersicht über den Einzelfall und Kontinuität in den Untersuchungsbefunden gewährleistet.

2. Größerer Zeitaufwand pro Patientin für Aufklärung, Befragung und Untersuchungen, die routinemäßig sonst nicht in gleichem Umfange erfolgen können.

3. Vaginale Untersuchungen alle 2-4 Wochen, falls nicht noch häufiger indiziert. Protokollierung des Zervixbefundes (Fig. 4).

4. Einsatz der sehr frühzeitigen ambulanten Tokolyse mit $\beta$-Mimetika bei mehr als 10 Kontraktionen/Tag oder mehr als 5 Kontraktionen/Tag von mehr als $40 \mathrm{sec}$. Dauer. Dosierung: Partusisten $®$ (Th 1165a) $6 \times 1,25 \mathrm{mg}$ bis $6 \times 2,5 \mathrm{mg}$ täglich $(1 \mathrm{Tab} . .=2,5 \mathrm{mg})$ bei Bedarf in Kombination mit Isoptin® retard (Verapamil) je nach Stärke der Nebenwirkungen bis $3 \times 120 \mathrm{mg}$ täglich (1 Drg. = $120 \mathrm{mg})_{\text {; , }}$

5. Kontrolle des fetalen Wachstums durch KephaloThorako-Metrie mit Ultraschall alle 2-4 Wochen (Protokoll Fig. 5).

Bei verdächtigen Verläufen HPL-Bestimmungen zum Erkennen einer nutritiven Plazentarinsuffizienz.

6. In der Spätschwangerschaft Amnioskopie und Kardiotokographie zur Feststellung einer respiratorischen Plazentarinsuffizienz.

Die Durchführung des PDP-Programmes erfordert einen erheblichen personellen und apparativen Aufwand. Doch schon unsere kurzen Erfahrungen zeigen, daß es geeignet ist, die Rate der untergewichtigen Kinder deutlich zu senken.

Schlüsselwörter: Dysmaturität, Kephalo-Thorako-Metrie, Prämaturität, Risikoliste, Schwangerenvorsorge, Tokolyse.

\section{Résumé}

Premiers résultats et expériences de notre Programme de Prévention de Prématurité et de Dysmaturité (Programme PDP)

La majorité des enfants morts ou souffrant de lésions en période périnatale figurent dans le groupe des nouveaux-nés dont le poids à la naissance est au-dessous de la norme $(<2500 \mathrm{~g})$. La médecine obstetrique et périnatale devra donc s'efforcer de réduire le nombre des enfants de ce groupe. C'est en 1971 que nous avons commencé l'application de notre Programme PDP centré sur la Liste PDP qui est établie à la première consultation de grossesse et complétée aux visites ultérieures. La Liste comporte un catalogue de $\mathbf{3 6}$ facteurs de risque, divisés graphiquement en dits »facteurs fixes« (dont la charge n'est plus corrigible) et en facteurs corrigibles ou traitables, avec différenciation également selon leur degré d'importance relatif au risque de prématurité ou de dysmaturité. La première année d'application, la Liste PDP I juxtaposait les facteurs sans hiérarchie des valeurs. $\mathrm{La}$ deuxième année et après évaluation des résultats, on a tenté d'ordonner par degré d'importance les divers facteurs selon un système de points: la Liste PDP II (Fig. 1).

Un risque précis prématurité existe à partir de 6 points et audessus (Fig. 2), un risque de dysmaturité à partir de 6 points (Fig. 3). Environ 40 pour cent des femmes enceintes atteignirent chez nous ce nombre de points et elles furent suivies dans une consultation spéciale, instituée à leur intention. Les résultats des deux premières années figurent au Tab. I. La première année (partie supérieure de Tab. I) nous n'avons pu enregistrer que tout juste 30 pour cent des femmes enceintes sur la Liste PDP à cause du travail supplémentaire que cela demandait. On compta dans ce Groupe III 1,9\% de moins d'enfants avec insuffisance de poids que dans le Groupe II non recensé. La deuxième année (partie inférieure du Tab. I), cette différence atteignit $3,6 \%$, ce qui représente une diminution globale des enfants de poids insuffisant supérieure à 35\% (statistiquement significatif avec $\mathbf{p}<0,01$ ).
Le Tab. II résume une différenciation plus détaillée et précise du Groupe III du Tab. I. La première année, le pourcentage des enfants de poịds insuffisant du Groupe B (considéré d'après la Liste PDP I comme "non en danger ») était de $5,7 \%$, soit encore trop élevé. Grâce à l'application de la Liste PDP II la deuxième année, le pourcentage de ces enfants du Groupe B a pu être abaissé à 1,6\%. La baisse est, avec $p<0,005$, statistiquement significative et prouve l'amélioration de la sélection par le système de points de la Liste II.

La consultation PDP se distingue chez nous des autres consultations de clinique par les diverses réglementations suivantes:

1. Observation de la patiente toujours par le même médecin pour garantir un examen global meilleur et plus continu de chaque cas particulier.

2. Temps plus long consacré à chaque patiente pour la consultation et les examens qui, normalement, ne peuvent pas être pratiqués à la même échelle.

3. Examens vaginaux toutes les $2-4$ semaines, ou même plus souvent si cela s'avère nécessaire, avec rapport du résultat cervical (Fig. 4).

4. Application de tocolyse ambulatoire avec $\beta$-mimétiques en cas de plus de 10 contractions/jour ou de plus de 5 contractions/jour d'une durée supérieure à $40 \mathrm{sec}$. Dosage: Partusisten® (Th 1165a) $6 \times 1,25 \mathrm{mg}$ à $6 \times 2,5 \mathrm{mg}$ par jour ( 1 comprimé $=2,5 \mathrm{mg}$ ), si necessaire en combination avec Isoptin ${ }^{\circ}$ retard (Verapamil) selon l'acuité des effets secondaires à $3 \times 120 \mathrm{mg}$ par jour (1 dragée $=120 \mathrm{mg}$ ).

5. Contrôle de la croissance foetạle par céphalo-thoracométrie avec ultrason toutes les $2-4$ semaines (Fig. 5).

En cas de développements suspects, déterminations HPL (Human Placental Lactogen) pour reconnaître une insuffisance placentaire nutritive.

6. En fin de grossesse, amnioscopie et cardiotocographie pour dépister une insuffisance placentaire respiratoire éventuelle. 


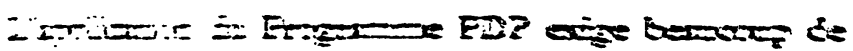

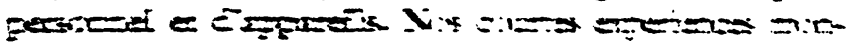

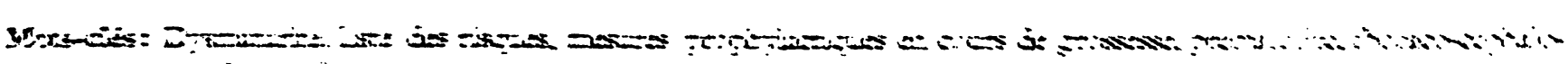

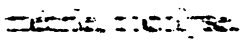

\section{$5=20=$}

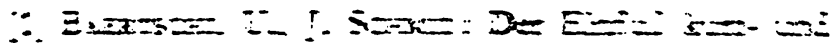
نE

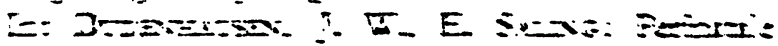
QI

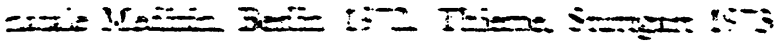

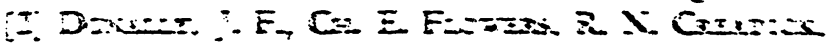
$\because$ E

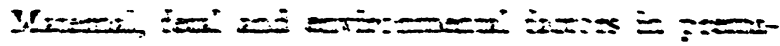
드.

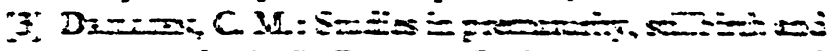

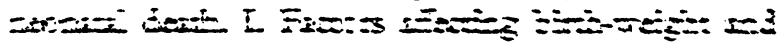

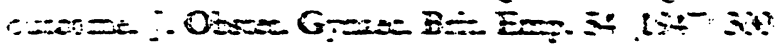

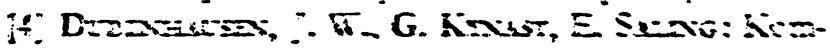

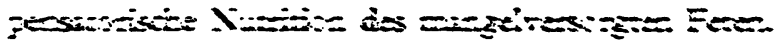

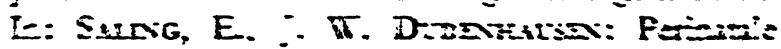

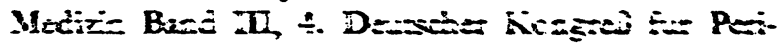

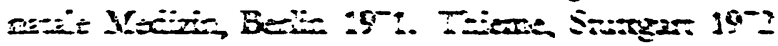

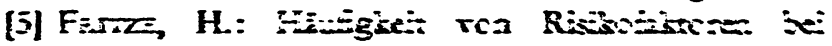

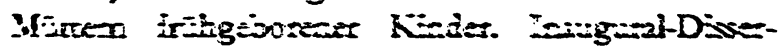

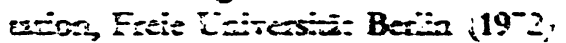

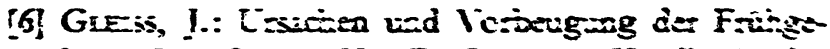

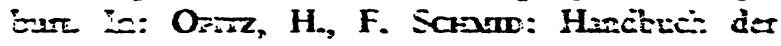

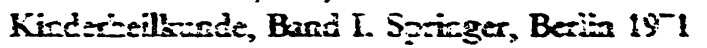

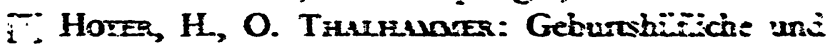
sozioñtonomiscie Fakroren in der Geces der Frï:getur. Gebursh. u. Fraeniceilk, 23 ;196s) 798

[8] Lxdwig, H: Patiologische Fibriniecusg bei Spä!gestose. In: Ropruali, E T.: Die Spärgestose. Scizrabe, Basel 19:0

[9] Mosier, K. H.: The drmamics of urerine muscle. Adrances in Obstecrics and Grnaecology, Vol. 35. Karger, Basel Nex- York 1968

[10] Papierstik-Berkhaler, E.: Coefficiear de risque d'accouchement prémarué (C. R. A. P.). Presse mèd. 77 (1969) 793

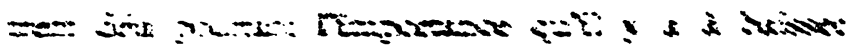

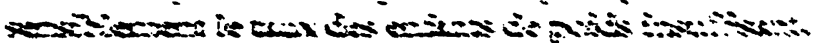

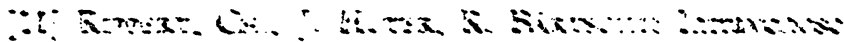

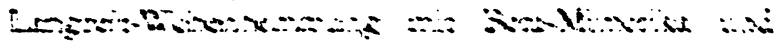

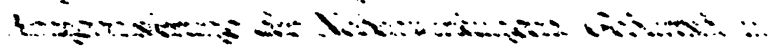

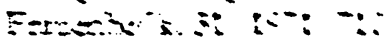

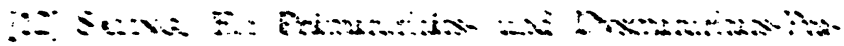

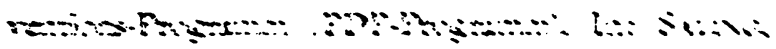
E

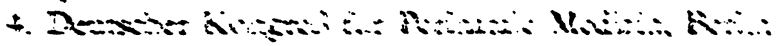

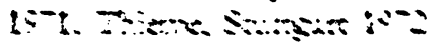

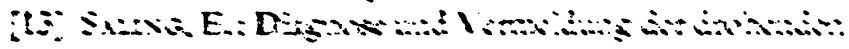

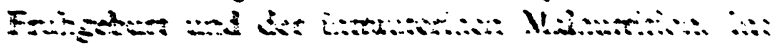

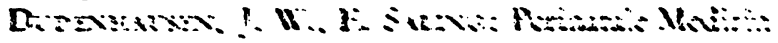

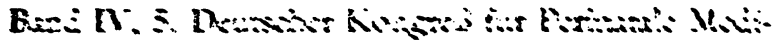

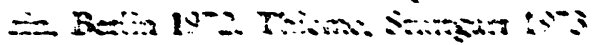

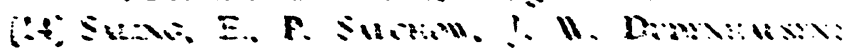

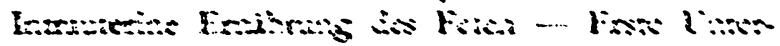

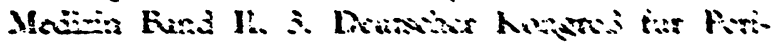

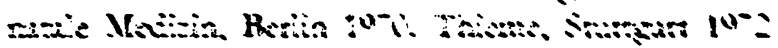

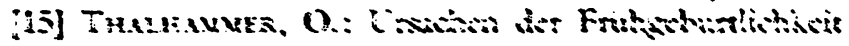

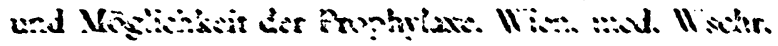
110 (ISm) sop

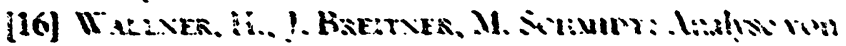

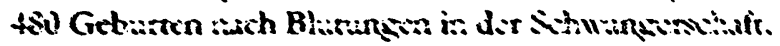

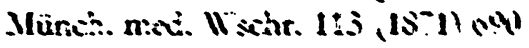

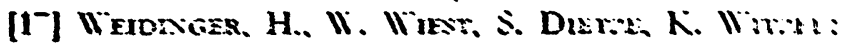

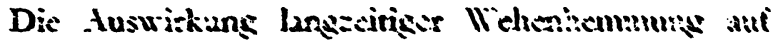
das sicugeborenc und den Singlings. In: Dinti-

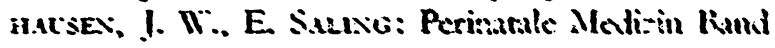
N, 5. Deursciner Kongrels fur Perinatale Mlenioin. Berlin 19-2. Thicme. Sturtyart 19-3

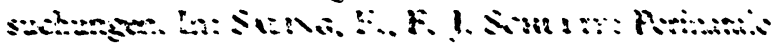

1. M. Gitfici

Prof. Dr. F. Solingr

Linit of Perin.tral Mledicine

Maricndorfer 110 en $28-3 s$

D-1000 Berlin 4t: Cicmun! 